\title{
Mykola Khvyl'ovyy and the making of Soviet Ukrainian literature
}

\author{
Olena PALKO \\ Postdoctoral Researcher \\ Birkbeck University of London, London (UK) \\ o.palko@bbk.ac.uk
}

\begin{abstract}
The October Revolution brought about a radical shift in the cultural sphere. A new generation of artists and writers was formed. Their orientation towards the future and critical attitude to the past initiated a new chapter of revolutionary and proletarian culture. In Soviet Ukraine, this new artistic cohort in addition embraced national sentiments advancing a culture that was both Soviet and Ukrainian. This article examines the artistic and ideological development of Mykola Khvyl'ovyy (1893-1933), a writer and publicist who championed the ideological struggle for the autonomous project of a Soviet Ukrainian literature to be developed independently from Russian patterns. In this article, Khvyl'ovyy's ideas as presented in his early prose and pamphlets, written during the so-called Literary Discussion of 1925-1928, are used to outline the writer's vision of Soviet Ukrainian culture. These ideas are examined against the backdrop of the political developments of the decade characterised by the gradual toughening of the political and ideological climate Union-wide. It is argued that, during the 1920s, an autonomous cultural project in Soviet Ukraine was developed on a par with the centrally endorsed canon of all-Soviet culture implemented in every Soviet republic as a by-product of the korenizatsiya (indigenisation) campaign introduced in 1923. By the early 1930s, the all-Soviet canon gained prominence, whereas the project of an autonomous Soviet Ukrainian culture vanished together with its main representatives, who, in most cases, were physically annihilated. Khvyl'ovyy's suicide in May 1933 symbolically drew a line under the 1920s decade of transition, with its relative ideological and political tolerance as well as its artistic experimentation.
\end{abstract}

Keywords: Mykola Khvyl'ovyy, Soviet Ukraine, Soviet Ukrainian culture, national communism, Soviet Union, korenizatsiya.

\section{Résumé}

La révolution d'Octobre provoque un changement culturel radical qui voit la formation d'une nouvelle génération d'artistes et d'écrivains. Avides d'avenir et critiques envers le passé, ils ont ouvert un nouveau chapitre de la culture révolutionnaire et prolétarienne. En Ukraine soviétique, cette nouvelle cohorte artistique a également intégré les sentiments nationaux afin d'aller vers une culture à la fois soviétique et ukrainienne. Cet article s'attache au développement artistique et idéologique de Mykola Khvylovy (1893-1933), un écrivain qui était à l'avant-garde de la lutte pour une littérature ukrainienne soviétique indépendante des modèles russes. Il s'est exprimé à ce sujet lors de la « Discussion littéraire » de 1925-1928, dans sa prose comme dans ses premiers pamphlets, et il faut situer ses prises de position dans le contexte politique d'un durcissement idéologique progressif dans toute l'Union soviétique au long des années 1920. Nous avançons l'hypothèse suivante : un projet culturel autonome avait alors été développé en Ukraine soviétique en parallèle à celui qui était promu de façon centralisée en URSS. Ce modèle culturel général devait être décliné dans chaque république soviétique en application de la campagne de korenizatsia (indigénisation) introduite en 1923. Au début des années 1930, ce modèle culturel pan-soviétique a pris le dessus alors que le projet d'une culture ukrainienne soviétique autonome disparaissait avec ses principaux représentants. Dans la plupart des cas, ils ont été physiquement éliminés. En mai 1933, le suicide de Khvylovy a symboliquement tourné la page des années 1920, une décennie de transition, ouverte à l'expérimentation artistique et à un relatif pluralisme idéologique et politique.

Mots-clés : Mykola Khvylovy, Ukraine soviétique, culture ukrainienne soviétique, communisme national, Union soviétique, korenizatsia. 


\section{Mykola Khvyl'ovyy and the making of Soviet Ukrainian literature}

In March 1924, the best-selling Moscow author Boris Pil'nyak was invited to a literary evening in Kharkiv. Pil'nyak was well known in Soviet Ukraine. His recently published novel Naked Year [Голый год] (1920) was highly praised by both young revolutionary writers and admirers of Russian modernism. Moreover, it created a real fashion for Pil'nyak, when a great number of imitators started copying his ornamental style and highly metaphorical use of language. At the same time, other contemporary authors were not considered to be innovative only because their style reminded critics of Pil'nyak. This was the case of perhaps the most prominent Ukrainian revolutionary writer Mykola Khvyl'ovyy, who was often called the "Ukrainian Pil'nyak" (Лейтес 1925, 22).

In fact, it was Khvyl'ovyy's idea to invite Pil'nyak to the then Soviet Ukrainian capital. The literary evening was organised in such a way that Pil'nyak could present his latest prose and the Ukrainian writers could introduce their Russian fellow to literary developments in the Soviet republic. The event, however, ended with a scandal. The Ukrainian audience did not appreciate Pil'nyak's prose. From their perspective, it was simply not revolutionary enough. Khvyl'ovyy prepared a scathing review of the event, which was published shortly thereafter in the literary supplement to the official newspaper Visti [News]. In the review, he called Pil'nyak "a bard of a moribund noble estate” (Хвильовий 1924, 3). Khvyl'ovyy was frank about the intentions behind the invitation of the Russian writer to Kharkiv. According to him, the literary evening was intentionally organised to show Pil'nyak and other Russian writers that Kharkiv was not a Russian (russkaya) province, but the capital of a separate Soviet republic. In private correspondence from around the same time, Khvyl'ovyy explained that writers in Kharkiv took a militant stand against all "the brazen fellows, Mayakovskys [...] and all the dandies from the Moscow bohemia," who denied the existence of Ukrainian literature (Хвильовий [1924] 2013, 251).

There are at least two considerations that make this literary episode important for the study of early Soviet history in Ukraine. The first concerns the republic's cultural development, while the second refers to the complicated centre-periphery relationship within the Soviet Union. The revolutions of 1917 brought to the fore two competing views of the future Ukrainian Soviet culture. First, there was a

CONNEXE 5 | 2019 - Divided Memories, Shared Memories, Poland, Russia, Ukraine: History mirrored in Literature and Cinema 
distinct project for a Soviet Ukrainian culture curated from Kharkiv, supported by the politician Oleksandr Shums'kyy and championed by the writer Khvyl'ovyy. Second, the project for an all-Union culture was promoted by Moscow-oriented party members, according to which the Russian capital remained the centre of cultural trends, which were copied by, or transferred to the peripheries. For Khvyl'ovyy, Pil'nyak, the long-standing head of the Russian Writers' Union represented this centralist view of cultural development in the Soviet Union. The events of 1917-1921 had initiated a split between the Ukrainian and Russian cultural elites, as well as two different perspectives on Soviet culture that reached its peak during the so-called Literary Discussion in the mid-1920s. This debate continued incessantly for almost three years between 1925 and 1928, and at various times involved the most prominent artists and politicians in Soviet Ukraine and Moscow, including Stalin himself (Коряк 1928; Ведмідський 1932; Ковалів 1990; Luckyj 1990; Shkandrij 1992). This gap was bridged only through direct state intervention in the cultural sphere leading eventually to the realignment of political and cultural forces in Soviet Ukraine after 1926. By examining the literary debates of the early 1920s, this article suggests a competition between two different cultural projects in Soviet Ukraine and suggests the reasons for the eventual triumph of the all-Soviet cultural canon after 1932.

\section{1. "I wanted to be a Ukrainian communist"}

Mykola Khvyl'ovyy (real name Fitil'ov) was born to a teachers' family in 1893 in the town of Trostyanets' in Kharkiv gubernia. He shared his father's interest in the revolutionary movement of the 1860s, sympathised with the ideology of the former Russian populists (narodniki) and was equally inspired by the works of Nikolay Dobrolyubov, Vissarion Belinskiy and Dmitriy Pisarev (Хвильовий 1991, 840). With the financial support of his relatives, Khvyl'ovyy entered a gymnasium school in Bohodukhiv in 1909, which he was soon asked to leave due to his links to a "so-called Ukrainian revolutionary circle" (Хвильовий 1991, 830). By now listed by the authorities for his continued agitation against the regime, Khvyl'ovyy, in order to escape possible persecution, left for Donbas in 1910 where he took up odd jobs at various industrial sites. In 1914, he was drafted into the Imperial Russian Army and the next year sent to the front as a private. What followed was "three years of marches, hunger, terrible horror that I would not dare to describe; three years of squared Golgotha on the distant fields of Galicia, Carpathians, Romania and so on and so forth" (Хвильовий 1991, 852).

By early 1917, Russia was losing the war; morale was low, desertion became a norm. At home, there was high inflation and severe food shortages. The tsar lost 
the support of both the army and the people. Popular demonstrations against the tsar became widespread. On March 2, Tsar Nicholas II abdicated, and a Provisional Government was formed in Petrograd. It was intended as a caretaker administration until elections could be held for an all-Russia Constituent Assembly, which would decide the future of the empire. The establishment of the Provisional Government in Petrograd was enthusiastically greeted on the frontline. Soviets (councils) of soldiers' deputies were established in the garrisons to control the situation and discipline until the election of a constituent assembly scheduled for November that year. At the time of the February Revolution, Khvyl'ovyy was in Romania. He became associated with the Ukrainian Party of Socialist Revolutionaries (UPSR), an important political player in the newly created Central Rada - a national legislative authority established on March 4, 1917 in response to the events in Petrograd. As the 1917 wore on, however, he, like many others at the front, started siding with the Bolsheviks, whose demands for immediate peace began to gain support.

Khvyl'ovyy embraced the revolution wholeheartedly. For him, two different revolutionary movements coincided in Ukraine and Russia. The revolutionary upheaval in Ukraine was even more profound than in Russia, aiming to achieve both social justice and national liberation. As observed by O. Han, one of the first biographers of the writer:

Khvyl'ovyy with distinct expansive ardour threw himself into the abyss of political struggle, which was seething in Ukraine. An enthusiast of the Ukrainian national affairs [...], full of political extremism, he became an ardent adherent of a future Ukrainian state, in which questions of national and social emancipation would finally be resolved (Ган 1947, 19).

As later recalled in his memoirs, in early 1917, Khvyl'ovyy, a combatant and a member of the soldiers' committee, arrived at the congress of soviets in Romania with two ribbons pinned to his collar: a red and a yellow-and-blue one. He offered a simple yet symbolic account for his dual political views: "I wanted to be a Ukrainian Bolshevik" (Хвильовий 1987, 107). After his return from the frontline, Khvyl'ovyy joined the pro-Ukrainian leftist circles of the Ukrainian People's Republic (UNR), formed on November 20, 1917, and proclaimed independent on January 22, 1918. He continued to support the UNR even after the coup organised by the Central Powers in April 1918 that brought to power the conservative government of Pavlo Skoropads'kyy. Khvyl'ovyy formed a volunteer unit of Free Cossacks (vil'ne kozatstvo) that actively engaged in combat with the German and Ukrainian army units. Nonetheless, the weakening UNR soon adopted emergency measures to dissolve all paramilitary units and an order was issued for Khvyl'ovyy's arrest, 
which he miraculously managed to escape. Following this incident in early 1919, Khvyl'ovyy, as he later admitted, "fully accepted the Bolshevik ideology" and joined the Bolshevik party (Хвильовий 1991, 834). In 1924, he explained his predisposition by the fact that "the Bolsheviks went hand in hand with the Ukrainian parties seeking Ukraine's independence” (Хвильовий 1991, 832). Whatever the reason, Khvyl'ovyy welcomed the "decentralised power of soviets" and got actively engaged in building a new soviet Ukraine (Хвильовий 1991, 832).

\section{Searching for directions for proletarian culture}

In order to understand Khvyl'ovyy's critical stand against Pil'nyak in 1924, his perspective on Soviet Ukraine's cultural development must be considered. Khvyl'ovyy was widely recognised as a leader of the artistic generation of the 1920s and became a champion of a distinct project for Soviet Ukrainian culture, that was meant to be equally Soviet and Ukrainian (Fowler 2017; Palko 2020) ${ }^{1}$. This perspective was initiated shortly after the February revolution of 1917 that allowed the Ukrainian cultural and political elites to finally break away from centralist imperial control and embark on an autonomous path of cultural development; and it was further strengthened by those promoters of the October Revolution who discerned its possibilities for addressing both national and social concerns.

This autonomous Soviet Ukrainian cultural project found strong support among Ukraine-minded Bolsheviks many of whom joined the Communist Party of the Bolsheviks of Ukraine (KP(b)U) from the Borot'bysty party. Up to their dissolution in March 1920, the Borot'bysty remained an important current of the radical left in Ukraine numbering some 15,000 members (Майстренко 1979, 74). The Borot'bysty believed that communism and nationalism were compatible, so the revolution in Ukraine could be both social and national (Любовець 2005; Majstrenko 1954; Palko 2018). They wished to build a self-standing soviet Ukraine with its own communist party. As the civil war ensued, however, the Borot'bysty started to seek cooperation with the Bolsheviks -their representatives joined the Soviet government, while their eventual merger with the $\mathrm{KP}(\mathrm{b}) \mathrm{U}$ allowed the Borot'bysty to further promote Ukraine's autonomy and cultural development from within the ranks of the ruling party.

1 This article builds upon the recent study by Mayhill C. Fowler, Beau Monde on Empire's Edge: State and Stage in Soviet Ukraine (University of Toronto Press: Toronto, 2017). Fowler maintains that the 1920s' creative generation contributed to developing "something entirely new: Culture both Soviet and Ukrainian, in an entirely new place called Soviet Ukraine" (4). Fowler's study of the theatre in Soviet Ukraine offers an excellent case study for examining the non-linear developments in the cultural sphere of the 1920s-1930s. In this article, the author wishes to introduce yet another case study: Mykola Khvyl'ovyy, who due to his strong national orientation and ideological convictions best represented Soviet Ukrainian literature. 
Their influence was especially significant in the cultural sphere, which the Bolsheviks had neglected in the frenzy of the civil war. As early as May 1919, the Ukraine's Commissariat for Education, Narkomos, was handed over to the Borot'bysty leader, the poet Hnat Mykhaylychenko, who was succeeded by Mykhaylo Panchenko, Shums'kyy and Hryhoryy Hryn'ko. ${ }^{2}$ Under the auspices of the Narkomos, an All-Ukrainian Publishing House (Vsevydav) was established in May 1919. Vsevydav, later renamed the State Publishing House of Ukraine (Derzhavne vydavnytstvo Ukrayiny, DVU or Derzhvydav), enjoyed a privileged position in distributing printed material on the territory of Soviet Ukraine. The Borot'bysty also took control of Vseukrlitkom, a government agency in charge of the arts.

In fact, almost all cultural activities in Soviet Ukraine in the early 1920s were managed by the Borot'bysty. With Borot'bysty support, Vseukrlitkom made daring attempts to gather Ukrainian writers around the first Soviet-sponsored Ukrainian-language literary journal Mystetstvo [Art], edited by Ivan Blakytnyy and Mykhaylychenko in 1919-1920; and later its new publication Shlyakhy Mystetstva [The Paths of Art], published in 1920-1923. The former Borot'bysty also oversaw the leading Ukrainian monthly Chervonyy Shlyakh [Red Path] and the party biweekly Bil'shovyk Ukrayiny [The Bolshevik of Ukraine]. In summer 1921, Blakytnyy became the editor of the major daily governmental newspaper Visti VUTsVK [Ukrainian Central Executive Committee's News], turning it into the real heart of Ukrainian life in Kharkiv. The newspaper covered republican, all-Union and world news, publicised official Party pronouncements and commentaries. In addition, Visti had weekly cultural supplements Literatura, Nauka, Mystetstvo [Literature, Science and Arts], 1923-1924 and Kul'tura i Pobut [Culture and Everyday Life], 1924-1928, that provided a forum for new Ukrainian literature and the cultural debates of the decade.

In 1921, Khvyl'ovyy arrived in Kharkiv, where he quickly joined the circle of Ellan-Blakytnyy, who inducted the young writer into the city's artistic and intellectual milieu. A Ukrainian speaker, Khvyl'ovyy easily found a job in the Soviet apparatus, joining the Central Bureau of Political and Educational Work, Holovpolitosvita and later taking up work at the editorial house of Chervonyy Shlyakh -a "thick journal" published under the auspices of the Narkomos, with the then Commissar for Education Hryn'ko as its editor-in-chief, later replaced by Shums'kyy in the same capacity. Apart from the editorial work, Khvyl'ovyy also started a literary career. Soon after his arrival in Kharkiv, Khvyl'ovyy published

2 In October 1922-March 1924, the Narkomos was headed by the Bolshevik Volodymyr Zatons'kyy.

CONNEXE 5 | 2019 - Divided Memories, Shared Memories, Poland, Russia, Ukraine: History mirrored in Literature and Cinema 
two poetry collections -Youth [Молодість] in 1921, and Symphonies of the Dawn [Досвітні симфоніï] in 1922; both went virtually unnoticed. However, his first prose collection entitled Blue Etudes [Сині етюди] (1923) was an immediate success. His second collection Autumn [Осінь], published in 1924, cemented his fame as "one of the most outstanding writers of the proletarian age" (Дорошкевич 1927, 304).

It was not only his literary merit that raised Khvyl'ovyy among his fellow writers. Khvyl'ovyy came to represent the national dimension of proletarian literature and as such paved the way for an alternative vision of Soviet literature in Ukraine. He, like many other young writers, anticipated a new proletarian culture that would have the ability to match and fully reflect on the post-revolutionary social advances. In this endeavour, he stood on the same side as Proletkul't - a mass movement founded in 1917 in Russia by Alexander Bogdanov, intended to ensure proletarian dictatorship in culture against the alien culture of the bourgeoisie. The organisation was characterised by its nihilistic attitude toward the tradition and culture of the past, its belief in collective artistic production, and exclusive proletarian ethos (Mally 1990; Dobrenko 2005; Slonim 1964, 32-40). The first Proletkul't organisations were established in Ukraine in late 1918, with a separate Organisational Committee of Proletkul't formed in Kharkiv in autumn 1921. Their activity, however, was impeded by their disregard for the national differences within the movement. According to a Soviet source, Proletkul't

did not only fail to acknowledge Ukrainian national art, culture or language, but referred to the [Ukrainian] Soviet Republic as a 'region' [kray] (quoted from Ilnytzkyj 1998, 39).

With so little autonomy, Proletkul't could hardly become a platform for Ukrainian proletarian literature. It quickly lost its appeal even among those pro-soviet Ukrainian writers who were sympathetic to the Proletkul't's cause of bolstering the cultural potential of the proletariat, albeit "only through channels national both in content and form," as emphasised by the Commissar for Education Mykhaylychenko in his "Theses on Proletarian Art" [“Пролетарське мистецтво" (тези)] published in 1919 (Михайличенко [1919] 1928, II: 25-28).

While unhappy with Proletkul't, Ukrainian pro-soviet writers made several attempts to establish their own "organisation of the October literature" [zhovtneva literatura]. In late 1921, a group Zhovten' [October] was formed, comprising Khvyl'ovyy, Volodymyr Sosyura and Mayk Yohansen. The group published a manifesto, Our Universal [Наш універсал], defining their vision of a new proletarian literature created in Soviet Ukraine. Similar to Proletkul't, the group 
rejected the literature of the past and traditional methods of artistic expression and dedicated itself to creating literature that would satisfy the demands of the proletariat, this new victorious social class. Yet unlike the former, it highlighted the importance of the Ukrainian language, regarded as a link between the workers and "their thousand-year-long history and their ancestors -the Ukrainian peasantry" (Наш універсал 1921, 1-2). Those were the principles that laid the foundations for a new literary organisation -the All-Ukrainian Federation of Proletarian Writers and Artists, initiated by Khvyl'ovyy in January 1922. The organisation saw its task as "searching for directions for proletarian culture" and "educating the masses in a proletarian spirit" (Декларація Всеукраїнської 1922, 3-4). The federation was, however, short-lived, and its only success was a single issue of Arena, published in 1922.

While overwhelmingly rejecting Proletkul't's anti-Ukrainian stand, writers in Ukraine eagerly embraced its belief in collective artistic production and orientation towards the masses. Many pro-soviet writers who had previously belonged to the Borot'bysty group Zhovten' and used to cooperate with Proletkul't formed the core of a new literary organisation - the Association of the Proletarian Writers Hart (Tempering), established in 1923 by the former Borot'bysty member Blakytnyy. The organisation devoted itself to nurturing writers of proletarian origin and aligned with the party vision on the social function of literature. In a program document for his literary organisation entitled Without a Manifesto [Без маніфесту], Blakytnyy called on:

The proletarian writers of Ukraine, [...] who, using the Ukrainian language as the means of artistic expression, aim at creation of one international, Communist culture, and who spread Communist ideology and fight against the petit-bourgeois propertied ideology (Лейтес, Яшек 1928, II, 374).

While rejecting artistic talent as a necessary prerequisite for literary work, Blakytnyy believed that proletarian culture in Ukraine could be created through “practice, as well as specific constructive work" (Без маніфесту [1924] 1928, II, 95).

Although one of Hart's founding members, Khvyl'ovyy, had opposing views on the question of artistic standards and the audience. As early as 1923, Khvyl'ovyy, together with Oles' Dosvitniy and Mykhaylo Yalovyy voiced their objections to Blakytnyy's decision to open up Hart to the broad masses of population. The group, which became known as the "Olympians," created a faction with a symbolic name "Urbino," 3 arguing that art could not be used as a means of

3 A reference to the Italian city Urbino which became the predecessor of the Renaissance culture.

CONNEXE 5 | 2019 - Divided Memories, Shared Memories, Poland, Russia, Ukraine: History mirrored in Literature and Cinema 
general enlightenment. This group defended the idea that literature should not be diminished to suit middle-brow tastes but, on the contrary, should set up certain standards to encourage readers to raise their preferences. Eventually, Khvyl'ovyy's "Urbino" laid the foundation to a new literary association, the Free Academy of Proletarian Literature (VAPLITE), established in 1925. Thereafter, VAPLITE dedicated itself to defending the autonomy of the cultural sphere and advocating for high quality literature. According to Khvyl'ovyy, VAPLITE's mission was to revive artistic criteria and promote excellence by replacing the principle "give me quantity" by "let’s go for quality" (Khvylovy [1925] 1986, 139). Unlike its rivals, VAPLITE did not intend to teach the proletariat how to produce good literature. The members of the academy shared a similar concern for quality, artistic integrity and originality and developing a "high culture" (Луцький 1977, 10). Its mission was to produce worthwhile literature for the proletariat, hoping that its audience would simultaneously cultivate their own level of cultural awareness through which to appreciate it. The Academy published a literary almanac Vaplite (1926) and a journal VAPLITE, five issues of which appeared in 1927 and featured poetry and prose, alongside critical studies, book reviews, political and social essays.

\section{3. "One should not confuse our political union with literature"}

Khvyl'ovyy was well aware, however, that in order to succeed with pursuing his vision of high-quality proletarian literature, Ukrainian culture needed first to overcome its century-long dependency on Russian cultural trends. In one of his pamphlets written during the Literary Discussion, Khvyl'ovyy questioned: "By which of the world's literatures should we set our course?" and immediately provided a definite and unconditional answer: "On no account by the Russian. [...] Ukrainian poetry must flee as quickly as possible from Russian literature and its styles" (Khvylovy [1925] 1986, 222). His determination was caused by a number of factors, the combination of which made cultural orientation towards Moscow detrimental for the new Soviet Ukrainian culture. First, it was thought, young Ukrainian writers had nothing to learn from their Russian fellows. Russian great literature, written during the nineteenth century, according to Khvyl'ovyy, had no examples of an active citizen, a determinant feature for future cultural development. A "passive pessimism," claimed to be an inherent feature of the Russian classics, led to producing "cadres of 'superfluous people', or to put it simply parasites, 'dreamers', people 'without any given responsibility', 'whimperers', 'grey little people' of the 'twentieth rank"' (Khvylovy [1926] 1986, 229). For him, the golden age of Russian literature had already passed in the nineteenth-century times of "feeble nobility" and feudalism. He called new writers to seek new inspiration 
and reject the orientation towards Russia: "Death to Dostoyevskism! Up with the cultural renaissance!” (Khvylovy [1926] 1986, 223-234).

Similarly, Russian proletarian literature had nothing to offer. For the writer, Moscow was a centre of "all-Union Philistinism" that "essentially never saw the October revolution and its heroic struggle" (Khvylovy [1926] 1986, 228-229). Moscow, a new Soviet capital, for Khvyl'ovyy was a centre of bureaucracy and perverted revolutionary slogans. With its borrowed proletarian ethos, Russian literature was unable to kindle a belief in the "commune behind the hill," a common metaphor used by Khvyl'ovyy to define his idealistic view of the revolution. In addition, he detested the chauvinist attitude of numerous Russian writers, who regarded the Ukrainian language only as a vernacular, and Soviet Ukraine as a mere province of Russia. One of such examples was a well-publicised incident with a Ukrainian translation of Maxim Gor'kiy's famous 1906 novel Mother [Мать]. In 1926, Oleksa Slisarenko, the editor-in-chief of the Knyhospilka editorial house, had written to Gor'kiy seeking his approval for the Ukrainian translation of the novel's abridged version. In his response, Gor'kiy had strongly objected to any changes to the original Russian text, refusing to endorse its translation into what he termed "the Ukrainian dialect (narechie)" (Лист О.М.Горького [1926] 1994, 149). Justifying this stance, he maintained that the languages would soon merge, with Russian becoming the only one used throughout the Soviet Union. Gor'kiy's claims, unsurprisingly, provoked a negative response in Ukraine. In the pamphlet Ukraine or Little Russia? [Україна чи Малоросія?], Khvyl'ovyy recalled the incident and named Gor'kiy "a great chauvinist, a preacher of Russian messianism and 'a gatherer of the Russian lands' for the sake of Russia, and definitely not communism.” (Хвильовий [1926] 2012, 44).

Khvyl'ovyy believed that the revolution had initiated a distinct current in Ukrainian literature, which took a completely separate path from Russian literature. Nevertheless, he was well aware of Ukraine's backwardness. He explained it primarily through the lack of a "Faustian activist attitude," of an "inquisitive human spirit" characteristic of European civilisation. He often defined Ukraine as a "khokhlyandiya," "a classic country of cultural epigonism," of "servile psychology," which kept producing "sluggish artists capable only of repeating what has already been done before, of aping" (Khvylovy [1925] 1986, 124). To overcome this cultural backwardness, Ukrainian writers needed to adopt civic values offered by the European civilisation. As a matter of fact, his "Europe" was an ideological category. It was defined through certain qualities, the total of

4 It stems from ' $k h o k h o l$ ', an exonym to denominate Ukrainians, which dates back to the 17th century. 
which contributed to the creation of a "grandiose civilisation." Its advance was attributed to "the ideal of a civic person," intelligence and the value attached to any intellectual activity, as he said:

This is the European intelligent in the best sense of the word. This, if you like, is the sorcerer from Württemberg who revealed a grandiose civilization to us and opened up limitless vistas to our gaze. This is Doctor Faustus, if we conceive of the latter as the inquisitive human spirit (Khvylovy [1925] 1986: 120).

His understanding of "Europe" was not necessarily bound to a political system or limited by geographical borders. In the first cycle of pamphlets, entitled Thoughts against the current [Думки проти течіï], Khvyl'ovyy simply associated "Europe" with high standards of artistic work and set it against literary outputs created by the members of state-funded mass literary movements. These writers produced torrents of low-quality literature, which had inundated the republic's bookstores and libraries during the 1920s (Liber 1982; Palko 2019). The concept of "psychological Europe" was used to counterweight provincialism and epigone art, initiated by those mass literary movements. Khvyl'ovyy offered a vague definition of "Europe":

You ask: "Which Europe?" Take whichever you like, "past or present, bourgeois or proletarian, eternal or ever-changing". Because, to be sure, Hamlets, Don Juans or Tartuffes existed in the past, but they also exist today, they used to be bourgeois, but they are also proletarian, you can consider them "eternal," but they will be "everchanging" (Khvylovy [1925] 1986, 120).

Such re-orientation from Russian patterns towards Western techniques and manners was still conditional. Khvyl'ovyy did not just want to change "the conductor" for young Soviet Ukrainian literature; his idea was to adopt only those characteristics that were in short supply among Ukrainians (namely an active citizen, the value of intellect, intellectual activity, and civil society) and to enhance them with the romantic vitalizm which he and his followers had been perfecting since the early 1920s. His idea was as follows:

When we steer our course toward Western European literature, it is not with the goal of yoking our art to some other wagon bringing up the rear, but with the aim of reviving it after the asphyxiating atmosphere of backwardness. We will travel to Europe to study, but with a secret idea -after several years to burn with an extraordinary flame (Khvylovy [1926] 1986, 223-224).

Khvyl'ovyy continually attempted to separate culture from politics: "one should not confuse our political union with literature" (Khvylovy [1925] 1986, 124). His primary concern was how to make new Soviet Ukrainian literature original, self-sufficient and independent from the Russian trends. Nonetheless, 
Khvyl'ovyy and his followers quickly realised that a separate cultural tradition in Soviet Ukraine could only be possible if the centre-periphery relationship within the Soviet Union were redefined. In March 1926, in the last essay of the series Apologists of Scribbling [Апологети писаризмy], Khvyl'ovyy edged forward to expose the true reason for Ukraine's cultural backwardness. He stated that cultural revival in Soviet Ukraine could only be achieved if the new Soviet elites shrugged off their dependency on Russia in both the cultural and political realms. Khvyl'ovyy declared that Soviet Ukraine was independent as much as Russia was, and as such should be treated as an equal part in the Soviet Union:

In a word, the Union nevertheless remains a Union and Ukraine is an independent entity. [...] Under the influence of our economy, we are applying to our literature not "the Slavophile theory of originality," but the theory of Communist independence. [...] Is Russia an independent state? It is! Well, in that case we too are independent (Khvylovy [1926] 1986, 222).

This approach elaborated by the card-carrying communist was bizarre within the Soviet ideological framework of the time, to say the least, and it attracted the attention of the central party leadership. In a letter sent to the KP(b)U First Secretary on April 26, 1926, Stalin, among other issues, commented unfavourably on the latest trends in Soviet Ukrainian cultural developments (Хвильовий 19791986, V, 485-489; Luckyj 1990, 66-68). He referred to the pamphlets of the "noted Communist" Khvyl'ovyy. Particular attention was drawn to his "anti-Russian orientation". In the letter, Stalin questioned the overall ideological commitment of writers in Soviet Ukraine, if even a card-carrying writer Khvyl'ovyy promoted a messianic role for the new Ukrainian elites and Soviet Ukrainian exceptionalism. Stalin wrote:

At a time when the proletarians of Western Europe and their Communist Parties are in sympathy with "Moscow," this citadel of the international revolutionary movement and of Leninism, at a time when the proletarians of Western Europe look with admiration at the flag that flies over Moscow, the Ukrainian Communist Khvilevoy has nothing better to say in favor of "Moscow" than to call on the Ukrainian leaders to get away from "Moscow" "as fast as possible." And that is called internationalism! What is to be said of other Ukrainian intellectuals, those of the non-communist camp, if Communists begin to talk, and not only to talk but even to write in our Soviet press, in the language of Khvilevoy? (quoted from Luckyj 1990, 67-68).

Stalin's criticism initiated a broad political campaign against Khvyl'ovyy for his political views, as well as Shums'kyy who was accused of failing to control his protégé and allowing the cultural process in Soviet Ukraine to take a wrong direction. At the June 1926 Plenum of the Central Committee of the $\mathrm{CP}(\mathrm{b}) \mathrm{U}$, Khvyl'ovyy was accused of promoting the views of "the Ukrainian 
petty intelligentsia," of advocating "a bourgeois restoration" of Ukraine and its orientation towards a capitalist Europe, and of "distancing Ukraine from the fortress of the international revolution, the capital of the USSR, Moscow" (Лейтес, Яшек 1928, II, 300). These views were linked to the weaknesses of his proletarian consciousness inspired by inconsistences in the New Economic Policy (NEP). The high KP(b)U official Volodymyr Zatons'kyy suggested that many young communists became ideologically confused because of the permissive atmosphere of those years. Using Khvyl'ovyy as an example, he concluded that "one is not born a Bolshevik, rather one becomes a Bolshevik" (Будівництво радянської України 1929, I, 22). To that drifting youth, the Party should offer a helping hand in telling right from wrong:

From Khvyl'ovyy and Khvyl'ovyys we should temper true communists [...] who will be useful to the revolution, will not spread the poison of disbelief and liquidationism, but instead will assist the proletariat in its arduous everyday battle (Будівництво радянської України 1929, I, 22).

Only during the last session was Khvyl'ovyy given an opportunity to justify himself. While defending his version of Soviet Ukraine's cultural development, he admitted possible overstatements and was ready to accept criticism:

I concede that there could be some exaggerations in the ideas and concepts I have developed [...]. However, overall, I believe there are grains of truth. [...] Nonetheless, if the entire Plenum agrees on my errors, I should acknowledge them and stop. First of all, I am a disciplined member of the Party. ${ }^{5}$

Nonetheless, he did not cease agitating the political and cultural milieu. In summer 1926, he wrote his most inflammatory pamphlet -Ukraine or Little Russia? [Україна чи Малоросія?] in which he dared to raise the "most dangerous question of today" - “Is Ukraine a colony or is it not?” (Khvylovy [1926] 1986, 227). He utilised the term Malorosiya, or Little Russia (first coined in the 18th century to refer to Ukraine and Ukrainians in the Russian Empire) to define the colonial position of Ukraine still being promoted by some politicians. For him, the future of Ukraine was either the one of "Ukraine" - an independent and sovereign soviet republic, or of "Little Russia" - an integral part of Russia with no autonomy and decision-making authority.

What made the pamphlet so important for both Khvyl'ovyy's supporters and opponents was its penetrating critique of the existing centre-periphery relations in the Soviet Union, while Soviet Ukraine played only a subordinate part. Instead, Khvyl'ovyy defended the sovereignty of Ukraine and appealed for

5 Стенографический отчет Пленума ЦК КП(б)У, Центральний Державний Архів Громадських Об’єднань України (ЦДАГО), ф. 1, оп.1, спр.208, арк. 79-3в.-80-зв. 
extending the scope of Ukrayinizatsiya -the Ukrainian version of the all-Soviet policy of korenizatsiya introduced in 1923. Very much in line with the position of Shums'kyy, Khvyl'ovyy concluded:

We are indeed an independent state whose republican organism is a part of the Soviet Union. And Ukraine is independent not because we, communists, desire this, but because the iron and irresistible will of the laws of history demands it, because only in this way shall we hasten class differentiation in Ukraine. [...] To gloss over independence with a hollow pseudo-Marxism is to fail to understand that Ukraine will continue to be an arena for counter-revolution as long as it does not pass through the natural stage that Western Europe went through during the formation of nation-states (Khvylovy [1926] 1986, 227).

The brochure was quickly censored; it never reached print and remained unknown in Soviet Ukraine until 1990. Despite being censored, it continued to be used thereafter as evidence of Khvyl'ovyy's anti-Soviet position that exposed his incessant diversion from the party line.

\section{4. "From Deviation into Abyss"}

Once harshly criticised for his political pamphlets, Khvyl'ovyy returned to fiction. His creative writing, however, was gaining political resonance too. The first instalment of his novel The Woodcocks [Вальдшнепи], written during the summer of 1926, appeared in the fifth issue of the journal Vaplite in 1927. The main protagonist of the novel is the disillusioned communist and former Chekist Dmytriy Karamazov, married to Hanna, also a Chekist in the past and a party member. While on vacation Karamazov meets a young Russian holidaymaker, the nationalist Ahlaya and during their lengthy philosophical and ideological conversation, he falls in love with her. Ahlaya, disillusioned by the outcomes of the revolution in Russia, admires the potency of the Ukrainian movement and the Ukrainian revolution and anticipates Ukraine's national rebirth. She came to Ukraine and even learned the language so as to witness that national reawakening for herself. At first, she took an interest in Karamazov, but their conversations made it clear that Karamazov would not be the one leading Ukraine forward. She was sceptical of those revolutionaries of the Karamazov type, who "stopped at a kind of idiotic crossroads": being unable to formulate and form new ideologies, they were looking for "a good shepherd," "a safety valve" getting committed to yet another idea, this time of national rebirth (Khvylovy [1926] 1986, 63-64).

The sixth issue of Vaplite containing The Woodcocks's second instalment was confiscated immediately. The excerpts from the second part became known through Andriy Khvylya's extensive critical review From Deviation into Abyss 
[Від ухилу в прірву], published in 1928 (Хвиля 1928). Khvylya, the assigned critic for the novel, had no doubt that Karamazov was Khvyl'ovyy's alter ego - a disenchanted Marxist who was easily swayed by "a speaker of the young Ukrainian fascist bourgeoisie” Ahlaya (Хвиля 1928, 17). To the critic, Khvyl'ovyy's The Woodcocks proved that the writer, despite accepting the party position in summer 1926, remained unapologetic for his "nationalist deviation." Instead, Khvylya continued, the writer dreamt of the rebirth of a nation and "became the apologist of the young Ukrainian bourgeoisie," and ultimately of Ukrainian nationalism (Хвиля 1928, 25-26). Thereby The Woodcocks was not an artistic novel, but "a publicistic work dressed up in artistic garb," through which the writer wished to replicate the main concepts of his censored brochure Ukraine or Little Russia? (Хвиля 1928, 40-41). With this novel, Khvylya concluded, Khvyl'ovyy aimed to show that:

Soviet Ukraine is not Soviet, the dictatorship of the proletariat is not real, that the nationalities policy is a sham, that the Ukrainian people are backward and willless, that the great rebirth is still to come, and finally, that the party itself is an organisation of hypocrites (Хвиля 1928, 3).

In December 1927, Khvyl'ovyy received permission to travel abroad. The writer went to Europe allegedly to undergo a course of medical treatment for tuberculosis. In numerous private letters prior to his departure, the writer mentioned that his illness had worsened and that he suffered from neurosis (Любченко 1977, 37; Хвильовий 2013, 255). However, considering Khvyl'ovyy's influence in the artistic milieu, his trip could as well have been an exile (Kratochvil 1999, 35). For a few months he resided in Vienna and Berlin, from where he could hardly influence or address the flow of criticism against himself or The Woodcocks. As seen from his letter to Yalovyy dated February 7, 1928, Khvyl'ovyy was frustrated with the critique of The Woodcocks and his recurrent persecution: "What do they want from us? To lick their butts? If there was no The Woodcocks, they would have found something else to accuse me of." Even more painful for Khvyl'ovyy were rumours of his political dissent. Aggravated, he retorted: "I not only was not thinking of giving back my party card, but I will appeal to Stalin himself if anyone should think to take it from me." 7 This negative reaction to the condemnation of his theories as "national bourgeois" or even as a form of "Ukrainian fascism," raises the question of whether Khvyl'ovyy himself believed he was crossing the

6 Галузевий Державний Архів Служби Безпеки України (ГДА СБУ), Справа-Формуляр С-183, арк. 17-20: Excerpts from the censored letter of Khvyl'ovyy to Yalovyy dated from 7 February 1928, ark.19.

7 Ibid., арк.19.

8 In the resolution of the June 1926 Plenum, Khvyl'ovyy was accused of "disseminating the ideas of Ukrainian fascism.” See: ЦДАГО, ф.1, оп. 20, спр. 6218, арк. 151. 
line of what was allowed and expected from a $\mathrm{KP}(\mathrm{b}) \mathrm{U}$ member. His reaction to those speculations might suggest that the writer himself did not regard his position as deviationist as the party leadership was trying to present it.

In fact, his position was determined by and remained in line with the programs of the Ukrainian communist parties, which sought an independent soviet Ukraine. He also sided with the KP(b)U leaders advocating Ukraine's autonomy in its broadest sense. In the transition period of the early 1920s, with all its inconsistences and social experiments, the Ukrainian communists cherished the hope that the project of Ukrainian statehood would still materialise. Khvyl'ovyy's attitude towards the $\mathrm{KP}(\mathrm{b}) \mathrm{U}$ remained ambivalent, however. Indeed, he opposed recent centralising tendencies, fearing that it would result in limiting Ukraine's cultural autonomy and the total subjugation of the republic to all-Union control. At the same time, he believed that the change could be introduced only from within. One might say that party membership was not merely a reflection of his ideological preferences; it provided him with the means to steer the course of actions in the literary sphere.

\section{5. "The Free Academy of Proletarian Literature is dead - Long live the State Academy of Literature!"}

From abroad, Khvyl'ovyy could hardly influence the situation in the literary sphere in Soviet Ukraine. During his stay abroad, VAPLITE, the literary organisation he had created to promote high-quality Soviet Ukrainian literature, was forced to self-liquidate. Hence, he needed to return to assure his fellow-writers that the battle for Soviet Ukrainian literature had not yet been lost. Khvyl'ovyy was the leader of his generation. Smolych, a writer only seven years his junior, called Khvyl'ovyy "a senior [starshyy] writer and a recognised literary authority" (Смолич 1968, 34). Aware of his status, Khvyl'ovyy used every opportunity to show his colleagues that the battle would continue. He concluded his letter to the writer Arkadiy Lyubchenko with an assertive note - "The Free Academy of Proletarian Literature is dead - Long live State Academy of Literature!” (Луцький 1977, 210).

His return to Soviet Ukraine was conditional, however. Khvyl'ovyy was expected to publicly repent his errors and assure the party of his loyalty. On February 22, 1928, his letter of recantation appeared in the party newspaper Komunist. The letter covered the main points of criticism raised by Khvylya against The Woodcocks and his previous pamphlets. He fully admitted every error and deviation attributed to him (Хвильовий 1979-1986, IV, 571). Не 
referred to a "psychological break" experienced during his absence: "What I've observed abroad made me finally realise that all this time I have been following a wrong path, not the one I should have taken as a communist" (Хвильовий 19791986, IV, 573). After his return, Khvyl'ovyy initiated another literary almanac -Literaturnyy Yarmarok [Literary Fair]. However, the almanac, of which twelve issues appeared between December 1928 and February 1930, was yet another attempt to preserve some elements of autonomy against tightening party control.

If the party wanted to compete with the autonomous project for a Soviet Ukrainian literature, it needed to do more than simply undermine its main proponents. There was a need for a state-sponsored literary organisation that could compete with VAPLITE both in the number of prominent members and the quality of their literary output. The new writers' union -The All-Ukrainian Union of Proletarian Writers, VUSPP, was established in late 1926. Its statute was adopted at the well-publicised first VUSPP congress held on January 25-28, 1927, where the main speakers included the Russian Commissar for Education Anatoliy Lunacharskiy himself (Маніфест Всеукраїнського З’ізду [1927] 1928, II, 233-236).

The VUSPP made no secret of its opposition to those writers promoting an autonomous cultural path for Ukraine. The latter were defined as "moderate bourgeois ideologists who only pretend to sympathise with the Soviet system." Allegedly, VAPLITE's influence was particularly harmful to those representatives of the Soviet cultural intelligentsia who remained "weak in their proletarian ideology" and whom it imbued "with a nationalist outlook, discouraging it from the creative path of the revolution, and [was inducing with] ideological scepticism, and a passive inertness which do not at all harmonise with the volitional and joyous psychology of the victorious class to which the future belongs" (quoted from Luckyj 1990, 76). Championed by trustworthy Soviet critics and writers such as Khvylya, Volodymyr Koryak, and Ivan Mykytenko, the VUSPP declared its readiness to wage the class struggle in the process of cultural construction against those writers who wished to create "a chasm between the proletarian cultures of Soviet Ukraine and Soviet Russia” (Маніфест Всеукраїнського 3”ізду [1927] 1928, II, 233). It advocated "the international union of proletarian writers" and sought close ties with the Russian Association of Proletarian Writers (RAPP).

The VUSPP statute resembled to the letter the new party resolution on "Policy of the Party concerning Ukrainian Literature," adopted in May 1927 (Будівництво радянської України 1929, I, 115-118; Luckyj 1990, 279-283). The Resolution encouraged Soviet Ukrainian writers to produce literature that 
would be proletarian -that is created in the proletarian environment by the new literary talent "from among the workers;" as well as mass-oriented. It defined literature as "the most important means of strengthening the union of the working class with the peasantry, a weapon of the proletariat in its direction of the entire Ukrainian cultural development." It also played an important role "in the cultural advancement of the masses of workers and peasants, in manifesting the building of a new socialist culture," in building socialism altogether (quoted from Luckyj 1990, 280).

Soviet proletarian literature, according to the Resolution, was to be created with the mass reader in mind. The authorities encouraged constant interaction with the audience, whereby authors would take inspiration from "the artistic qualities characteristic of the proletariat and their literary products would reflect "a continual mutual influence between the writers and the masses" (quoted from Luckyj 1990, 280). Genuine proletarian literature would be deductive, socially useful, ideologically correct and partisan. The Resolution stimulated proletarian writers "[to] most clearly define the social significance of their work, [to] definitely rid themselves of all bourgeois influences, and most attentively approach the task set for them by the party - of struggle against the anti-proletarian and counterrevolutionary elements, of combating the ideology of the new bourgeoisie" (quoted from Luckyj 1990, 279).

TheVUSPP was granted full party support, whereas other literary organisations and groupings needed to adapt their position and prove their loyalty to the party if they wished to retain access to publishing houses and distribution networks. In such circumstances, it became impossible for those non-affiliated writers to continue their literary activity (Смолич 1968, 141). In early 1930, after the almanac Literaturnyy Yarmarok was closed down due to its "opposition to socialist realist style," Khvyl'ovyy initiated yet another literary organisation -The Union of Workshops of the Proletarian Literary Front- Prolitfront (Декларативна передмова 1930, 5-10; Хвильовий [1930] 1979-1986, IV, 595-599). To comply with the 1927 resolution, the new organisation declared its adherence to the proletarian ethos and partisan ideology. Although seen by many as a last retreat for “independent” writers (Костюк 1987, I, 251-288; Luckyj 1990, 280), Prolitfront's activity during 1930-1931 signified a decline in the alternative project for proletarian literature in Ukraine. Gradually, the organisation embarked on the same path of accommodating the party vision on literature, as its ardent opponent -VUSPP.

Prolitfront fully embraced the party vision on literature as an immediate 
response to actuality and turned towards workers and peasants in search of themes and readers. In search of "shock-workers" of literature, the Prolitfront members got involved in various "useful" activities - organising tours to factories and collective farms, traveling to construction sites to collect material and plots for their works. Prolitfront opened their ranks to workers who were eager to master the literary craft and participate in "socialist competition for the best literary results" (quoted from Luckyj 1990, 158). They established literary circles at the workplace, assisted in publishing wall newspapers, organising literary evenings at which professional writers presented their work alongside talented worker youth. To provide a platform for these new voices, Prolitfront developed the idea of a bimonthly Literaturnyy Tsekh [Literary Guild], aiming to engage the young members of various literary studios established at Kharkiv factories. This idea, however, did not materialise. Eventually, in January 1931, Prolitfront selfliquidated. Its members passed a resolution declaring the need to consolidate the literary forces in the republic around the VUSPP. Their merger was justified since admittedly there were no ideological differences between the two (Хвильовий 1979-1986, IV, 607). The unification of these two groups marked the final stage in consolidating the literary forces in Soviet Ukraine.

\section{Soviet literature in Ukrainian}

In 1925, the major Soviet literary critic Koryak stated that Soviet writers were expected to put an end to "Ukrainian literature" and "Ukrainian poets" and start creating a universal "proletarian culture in the Ukrainian language" (Коряк 1925, 65). Until the 1930s, Koryak's perspective on literature was continually challenged, however. Throughout the 1920s, at least two visions of literature created by pro-soviet writers - Soviet Ukrainian literature and Soviet literature in Ukrainian, competed for the right to defend the path for Ukrainian literature, state financial support and most importantly, readers. The alternative project for proletarian literature in Soviet Ukraine, was launched in 1923 by three "Olympians" (Khvyl'ovyy, Dosvitniy and Yalovyy) who had decided to create a literary organisation dedicated to creating high-brow literature for educated and cultured proletarians. This alternative project for Soviet Ukrainian literature reached its zenith in the form of VAPLITE and Literaturnyy Yarmarok and exposed its strength during the Literary Discussion of 1926-1928. The ideological compliance of Prolitfront was not necessarily a rejection of those values; its members accepted the state of affairs to allow themselves a possibility to continue creative activity in the situation of toughened control and limited tolerance of artistic pluralism. Their merger with the VUSPP signalled the domination of 
one single view on Soviet literature, which was being created within a tightened ideological control and under close party supervision.

As reflected in his contributions from the early 1930s, Khvyl'ovyy steadily followed the same path of accommodating the intolerant mood of the period. In 1931, he became a VUSPP member and was now expected to prove his literary commitment to a "socially useful" understanding of Soviet literature. His short stories written during those years featured the most desired objects of the FiveYear Plan: workers, peasants, and exemplary party activists. Among his last stories were The Last Day [Останній день], Future Miners [Майбутні шахтарі], About Love [Про любов]. Apart from some rare exceptions, a devotion to the Soviet duty, loyalty and discipline became the main drivers for his later characters. His style had changed dramatically in those years. Instead of the ornate modernist prose of his earlier works, he adopted a realist optimistic style soon to be defined as "socialist realism." He also contributed to Soviet propaganda, writing journaliststyle essays on his trips to Soviet Ukraine's provinces. He toured through Kharkiv region, where he prepared nine sketches later published under the title Around the Barvinkove district [По Барвінківському району] (Хвильовий 1930; Хвильовий [1930] 1978-1986, III, 463-493). These sketches ridiculed religious practises, criticised former kulaks and wreckers, condemned recent violence against the Soviet authorities. At the same time, the reporter praised Soviet accomplishments in the social and cultural sphere - new hospitals, schools, libraries, reading rooms throughout resulting in the change of morals among the peasants.

On May 13, 1933, Khvyl'ovyy committed suicide. Earlier that year, at the height of the famine in Soviet Ukraine, the writer travelled with Lyubchenko, his close friend and a former VAPLITE secretary, to Poltava region in central Ukraine, commissioned to write positive reports from the countryside. Instead, he was struck by the extent of the famine there that, in his words was intentionally organised in order "to provoke resistance and, after having crushed it, to settle once and for all the dangerous Ukrainian problem" (Любченко 1960, 231).9 One can assume that his decision to take his own life was caused by disillusionment with the Soviet regime that he himself had once so ardently promoted. At the same time, it may have been a protest against Soviet centralisation as reflected in the policies implemented in Ukraine. To make matters worse, the authorities were

9 The partiality of the memoirs, however, is worth noting. Following the World War Two, Lyubchenko, one of many, ended up in exile and became an architect of the glorification narrative of the Ukrainian twenties in the diaspora historiography, later shaped within the "executed renaissance" paradigm. The memoirs, first published in 1943, could as well be used to adjust Khvyl'ovyy's persona to the demands of the new ideological narrative. 
ready to initiate yet another round of purges of the Ukrainian intelligentsia as suggested by the arrest of Khvyl'ovyy's close friend Yalovyy, the VAPLITE writer and its first president, accused in connection to an alleged counter-revolutionary Ukrainian Military Organisation, UVO.

It is believed that Khvyl'ovyy left two death notes (Palko 2016, 591-593), in which he claimed his responsibility towards the generation of the 1920s. The first note reaffirmed his adherence to communist ideology. It read:

Arrest of Yalovyy -this is the murder of an entire generation ... For what? Because we were the most sincere Communists? I don't understand. The responsibility for the actions of Yalovyy's generation lies with me, Khvyl'ovyy. Today is a beautiful sunny day. I love life -you can't even imagine how much. Today is the $13^{\text {th }}$. Remember I was in love with this number? Terribly painful. Long live communism. Long live the socialist construction. Long live the Communist Party. ${ }^{10}$

The second note provided instructions about his literary heritage.

Khvyl'ovyy came to represent an entire generation of disillusioned intellectuals, who witnessed the discrepancy between the ideals of the revolution and their implementation in Soviet Ukraine. His suicide signalled that there were no alternatives left but to comply with a centralist vision of Soviet Ukrainian literature. The adverse prospects were observed by the writer Hryhoriy Epik in his private conversation with Mykola Kulish: "You know, Mykola, whatever we write now, we will not be allowed, this is our end" (Хвильовий 1978-1986, V, 172). Even the memory of Khvyl'ovyy was considered dangerous for the authorities. Within a short period of time, his life-long activity was labelled counter-revolutionary, his writings were removed from libraries, and his name disappeared from official literary criticism. Until the early 1980s, his name could only be used in the Soviet Union in connection with "khvyl'ovizm" - a general term to define class enemies (Большая Советская 1935, 488). It is worth mentioning that Khvyl'ovyy was not rehabilitated in the course of the "Thaw" liberalisation in the 1950s. ${ }^{11}$

Institutional and ideological pluralism in the world of letters, as well as any competing visions of Soviet culture were put to an end by the 1932 Resolution "On the Restructuring of Literary and Artistic Organisations" according to which existing literary-artistic organisations "ha[d] become too narrow and [were] slowing the serious sweep of [literary and] artistic creativity" (Clark and Dobrenko 2007, 151-152). Nonetheless, by that time institutional diversity in literature remained only on paper and any ideological or aesthetic differences between the literary organisations and groupings had already faded away under the onslaught of the VUSPP (and RAPP in Russia). The party still wished to take

10 Copies of the death notes were accessed in Центральный державний архів-музей літературы і мистецтва України (ЦДАМЛМУ), Ф.1208, оп.1, спр.5, арк.1; спр.6, арк.1.

11 Khvyl'ovyy was rehabilitated in September 1989. See: ЦДАГО, Ф.39, оп.1, спр.819, арк.46-49.; спр.6, арк.1; ЦДАГО, Ф.1, оп.11, спр. 2224, арк.60.

CONNEXE 5 | 2019 - Divided Memories, Shared Memories, Poland, Russia, Ukraine: History mirrored in Literature and Cinema 
control back from those exclusive proletarian literary organisations and unify writers around common Soviet, rather than narrow proletarian values. Instead of intolerant proletarian literary associations, the 1932 Resolution provided for a single Union of Soviet Writers, which would embrace the new aesthetic method of socialist realism. The creation of the All-Soviet Congress of Soviet Writers in 1934 marked the completion of the organisational and ideological setup of Soviet literature, and an end to the competition between the two models of Soviet culture in Ukraine; Soviet culture, as defined centrally, achieved complete victory over the separatist vision of Soviet Ukrainian culture, ardently promoted by the Ukrainian communists and artists since the revolution.

\section{Bibliographical references}

Clark, Katerina, and Evgeny Dobrenko. 2007. Soviet Culture and Power: A History in Documents, 1917-1953. New Haven, CT: Yale UP.

Dobrenko, Evgeny. 2005. Aesthetics of Alienation: Reassessment of Early Soviet Cultural Theories. Evanston, IL: North-Western University Press.

Fowler, Mayhill. 2017. Beau Monde on Empire's Edge: State and Stage in Soviet Ukraine. Toronto, ON: Toronto UP.

Ilnytzkyj, Oleh S. 1998. Ukrainian Futurism, 1914-1930. A Historical and Critical Study. Cambridge, MA: Harvard UP.

Khvylovy, Mikola. 1960. Stories from the Ukraine. New York: Philosophical Library.

Khvylovy, Mikola. 1986. "Woodcocks." In Before the Storm: Soviet Ukrainian Fiction of the 1920s, edited by George Luckyj, 15-69. Ann Arbor, MI: Ardis.

Khvylovy, Mikola. 1986. The Cultural Renaissance in Ukraine. Edmonton, AB: CIUS.

Kratochvil, Alexander. 1999. Mikola Chvyl'ovyi: Eine Studie zu Leben und Werk. München: Verlag Otto Sagner.

Liber, George. 1982. "Language, Literacy, and Book Publishing in the Ukrainian SSR, 19231928.” Slavic Review 4: 680-681.

Liubchenko, Arkadiy. 1960. "His Secret.” In Stories from the Ukraine. 215-234. New York: Philosophical Library.

Luckyj, George S. N. 1990. Literary Politics in the Soviet Ukraine, 1917-1934. Durham, NC and London: Duke UP.

Majstrenko, Ivan. 1954. Borot'bism: A Chapter in the History of Ukrainian Communism. New York: Research Program on the USSR.

Mally, Lynn. 1990. Culture of the Future: The Proletkult Movement in Revolutionary Russia. Berkeley, CA: University of California Press.

Palko, Olena. 2016. "Between two Powers: A Soviet Ukrainian Writer Mikola Khvil'oviy." Jahrbücher für Geschichte Osteuropas 4: 575-598.

Palko, Olena. 2018. "Social and/or national revolution? Ukrainian communisms in the revolution and civil war." Socialist History 53: 69-90.

Palko, Olena. 2019. "Reading in Ukrainian: The Working Class and Mass Literature in early Soviet Ukraine." Social History 44(3): 343-368.

Palko, Olena. 2020. Making Ukraine Soviet: Literature and Culture in Soviet Ukraine under Lenin and Stalin. London: Bloomsbury.

CONNEXE 5 | 2019 - Divided Memories, Shared Memories, Poland, Russia, Ukraine: History mirrored in Literature and Cinema 
Shkandrij, Myroslav. 1992. Modernists, Marxists and the Nation: The Ukrainian Literary Discussion of the 1920s. Edmonton, AB: CIUS.

Slonim, Mark. 1964. Soviet Russian Literature. Writers and Problems. New York: Oxford University Press.

ХІІсъезд РКП(б).17-25 апреля 1923 .. Стенографический отчет. 1968. Москва: Политиздат. [Блакитний, Василь] “Без Маніфесту.” У О. Лейтес, М. Яшек. 1928. Десять років украӥнської літератури (1917-1927) 2, 82-95. Харків: ДВУ.

Большая Советская Энциклопедия. 1935. Том 59. Москва: Издательство “Большая Советская Энциклопедия."

Будівництво радянської Украӥни. 1929. Вип. 1. Харків: ДВУ.

Ведмідський, Олександр. 1932. Літературна дискусія, 1925-1928. Харків: Плужанин.

“Всеукраїнський Пролеткульт.” 1921. Шляхи мистещтва 1:62.

Ган, О. [Павло Петренко]. 1947. Трагедія Миколи Хвильового. [s.l.].

“Декларативна передмова до першого числа місячника “Пролітфронт.” 1930. Пролітфронт 1:5-10.

“Декларація Всеукраїнської Федерації Пролетарських Письменників і Митців.” 1922. Арена 1: 3-4.

Дорошкевич, Олександр. 1927. Підручник Історӥ Украӥнсъкої Лутератури. Київ: Книгоспілка.

Ковалів, Юрій. 1990. Літературна Дискусія 1925-1928. Київ: Знання.

Коряк, Володимир. 1925. Організація Жовтневої літератури. Харків: ДвУ.

Коряк, Володимир. 1928. Шляхи розвитку украӥнсъкої пролетарської літератури. Харків: ДВУ.

Костюк, Григорій. 1987. Зустрічі і прощання. Спогади. У 2-х томах. Toronto: CIUS.

Лейтес, О., и М. Яшек. 1928. Десять років украӥнської літератури (1917-1927). У 2-х томах. Харків:Є ДВУ.

Лейтес, Олександр. 1925. Ренесанс украӥнісъкої літератури. Харків: ДвУ.

“Лист О. М. Горького до О. А. Слісаренка від 7 травня 1926 р.” 1994. У Національні відносини в Украӥні в ХX ст.: Збірник документів і матеріалів, за ред. М. Панчука. 149. Київ: Наукова Думка.

Луцький, Юрій (ред.).1977. Ваплітянський Збірник. Oakwill: Mosaika.

Любовець, Олена. 2005. Украӥнські партї і політичні альтернативи. 1917-1920. Київ: Основи.

Любченко, Аркадії. 1977. “Спогади проХвильоіого: Із Записної книжки.”У Ваплітянський Збірник, за ред. Юрія Луцького, 33-46. Oakwill: Mosaika.

Майстренко, Іван. 1979. Історія Комуністичної Партіӥ Украӥни. Мюнхен: Сучасність.

“Маніфест Всеукраїнського 3”їду Пролетарських Письменників 28 січня 1927 р.” у о. Лейтес, М. Яшек. 1928. Десять років украӥнської літератури (1917-1927) 2, 233-236. Харків: ДВУ.

“Наш Універсал.” 1921. Жовтень 1: 1-2.

“Пролетарське мистецтво. Тези Гната Михайличенка на доповіді Всеукрліткому.” у о. Лейтес, М. Яшек. 1928. Десять років украйнської літератури (1917-1927) 2, 25-28. Харків: ДВУ.

CONNEXE 5 | 2019 - Divided memories, Shared memories, Poland, Russia, Ukraine: History mirrored in literature and cinema 
Смолич, Юрій. 1968. Розповідь про неспокій. Київ: Радянський письменник.

Хвильовий, Микола. 1924. “Пільняк, 'словоблудіє' і 'нєкій’ рецензент.” Культура і Побут $11: 3$.

Хвильовий, Микола. 1930. По Барвінківському районі. 3 бльокноту кореспондента. Харків: ДВУ.

Хвильовий, Микола. 1987. “Уривок з автобіографії.” вітчизна 12: 106-108.

Хвильовий, Микола. 1990-1991. Заг. ред. Станілав Мельников. Твори у Двох Томах. Київ: Дніпро.

Хвильовий, Микола. 2012. Украӥна чи Малоросія? Київ: Українська Прес-Група.

Хвильовий, Микола. 2013. “Листи.” Спадщина. Літературне Джерелознавство. Том VIII: 248-273.

Хвильовий, Микола. Заг. ред. Григорій Костюк. 1978-1986. Твори в П’ятьох Томах. НьюЙорк, Балтімор-Торонто: Смолоскип.

Хвиля, Андрій. 1928. Від ухилу у прірву. Харків: ДВУ. 